\title{
Immunization of mice with surface antigens from the muscle larvae of Trichinella spiralis
}

\author{
R.K.GRENCIS, C.CRAWFORD, D.I.PRITCHARD, \\ J.M.BEHNKE \& D. WAKELIN MRC Experimental Parasitology \\ Research Group, Department of Zoology, University of Nottingham, \\ Nottingham NG7 2RD, UK
}

Accepted for publication 14 May 1986

\begin{abstract}
Summary Surface antigens of muscle larvae of Trichinella spiralis were stripped from the cuticle of live worms by the cationic detergent cetyltrimethylammonium bromide (CTAB). Such antigen preparations were shown to contain surface antigens of approximate molecular weights $100000,90000,69000,55000,46000$ and 35000. Immunoprecipitation experiments confirmed that the surface of muscle larvae share antigenic epitopes with antigens contained within and secreted by the stichosome. CTAB antigen preparations were shown to be protective in NIH mice against a challenge infection as assessed by reduction in intestinal worm burden, worm fecundity, worm length and muscle larvae burden. The role of surface antigens in protective immunity to $T$. spiralis is discussed.
\end{abstract}

Keywords: surface antigens, Trichinella, immunity

\section{Introduction}

There is no doubt that the surface of parasitic nematodes is recognized as antigenic in many infected hosts (see reviews by Maizels, Philipp \& Ogilvie 1982, Philipp \& Rumjaneck 1984). In a number of experimental systems antibodies are produced against surface molecules and mediate antibody dependent cell mediated cytotoxic reactions (Butterworth 1985). Nevertheless, the importance of the nematode surface in generating protective host responses in vivo is still largely speculative due to the lack of suitable surface antigen preparations for use in vaccination studies. However, using a method originally developed for the isolation of protective viral surface antigens (Bachmayer, Liehl \& Schmidt 1976) our laboratory has shown that the cationic detergent cetyltrimethylammonium bromide (CTAB) is capable of selectively stripping surface antigens from a number of parasitic nematodes (Pritchard et al. 1985). The antigens obtained by this noninvasive technique are relatively pure and can therefore be used in vaccination studies.

In Trichinella spiralis the surface antigens of all the major life cycle stages of the parasite have been well defined using conventional iodine labelling techniques (ParkCorrespondence: Dr R.K.Grencis, MRC Experimental Parasitology Research Group, Department of Zoology, University of Nottingham, Nottingham NG7 2RD, UK. 
house, Philipp \& Ogilvie 1981). In vivo the most immunogenic life cycle stage is known to be the muscle larvae (Bell \& McGregor 1979a,b, 1980, Bell, McGregor \& Despommier 1979), and numerous studies have demonstrated that crude antigen preparations of this stage are capable of generating strong protection against reinfection in mice (see review by Silberstein 1983). Such protective muscle larvae antigens are thought to be derived primarily from the secretory granules of the stichosome (Despommier \& Muller 1970). Indeed Silberstein \& Despommier (1984) have recently purified two highly protective polypeptides from muscle larvae and demonstrated that these protective antigens are only present in the muscle larvae and pre-adult stages of the parasite (Silberstein \& Despommier 1985).

The $T$. spiralis/mouse model is therefore an ideal system in which to examine the protective nature of the surface antigens of the muscle larvae stage. As far as we are aware, the work presented here demonstrates for the first time that relatively pure surface antigen preparations are capable of stimulating protective immune responses against a parasitic nematode infection.

\section{Materials and methods}

\section{ANIMALS}

Female mice of the inbred NIH strain were bred and maintained at the Department of Zoology, University of Nottingham. All animals were used at approximately 8 weeks of age, in groups of six unless otherwise stated.

\section{PARASITE}

The strain of $T$. spiralis and the methods used in maintenance, infection, recovery and worm fecundity have been described by Wakelin \& Wilson (1977). Mean lengths of 25 adult female worms taken at random from each group were estimated using a camera lucida and an Apple graphics tablet/digitizer linked to an Apple IIe computer.

\section{PREPARATION OF ANTIGENS}

Muscle larvae homogenate used in protection experiments was prepared according to the methods described by Lee, Grencis \& Wakelin (1982). Labelled nematodes were homogenized in the presence of protease inhibitors and centrifuged for $30 \mathrm{~min}$ at $10000 \mathrm{~g}$ (Philipp, Parkhouse \& Ogilvie 1980).

CTAB antigen was obtained by incubating muscle larvae in CTAB dissolved in MEM Eagles medium to give a final concentration of $0 \cdot 25 \%(\mathrm{w} / \mathrm{v})$. Parasites were incubated at $37^{\circ} \mathrm{C}$ for the required time period, generally $1 \mathrm{~h}$ unless stated otherwise. The supernatant containing the muscle larvae antigens was then removed and centrifuged at $10000 \mathrm{~g}$ for 5 min. For animal experiments, the CTAB antigen preparation was dialysed against saline for 2-3 days at $4^{\circ} \mathrm{C}$ to remove the detergent, before protein estimation using the biorad assay. 
SURFACE LABELLING WITH ${ }^{125}$ I

Muscle larvae were labelled with ${ }^{125}$ I using the Iodogen method described by Pritchard $e t$ al. (1984).

\section{ANTISERA}

Immune sera for precipitation with antigen was obtained from rabbits that had received several $T$. spiralis infections.

The monoclonal antibodies to the $48 \mathrm{kD}$ polypeptide antigen (8A4.3.1.1) and the $50 /$ $55 \mathrm{kD}$ polypeptide antigen group (7B2.3.1.1) as described by Silberstein \& Despommier (1984) were a kind gift from Dr D.D.Despommier, Department of Microbiology and Division of Tropical Medicine, Columbia University, New York.

\section{BIOCHEMICAL ANALYSIS OF ANTIGENS}

SDS-PAGE was carried out in slab gels (Laemmli 1970) using a 7.5-20\% gradient gel. After running, the gel was stained with $1 \%$ Coomassie blue to visualize the protein bands and a densitometer tracing recorded using a Quick Scan R \& D electrophoresis/TLC densitomer (Helena Laboratories). The gel was then left to autoradiograph for 7 days. Immunoprecipitates for PAGE analysis were obtained by incubating $50 \mu \mathrm{l}$ of labelled parasite antigen with $100 \mu \mathrm{l}$ of immune serum (or monoclonal antibody) overnight at $4^{\circ} \mathrm{C}$. The precipitate was washed with PBS before use.

\section{IMMUNIZATION PROCEDURE}

Mice were immunized with the required amount of protein antigen divided into three equal doses. Antigen was injected intraperitoneally (i.p.) with Freund's Complete Adjuvant (FCA, Wellcome) on day -21 , followed by two i.p. injections of antigen alone on days -14 and -7 . Control animals received FCA/PBS instead of antigen. Challenge infections were given on day 0 .

\section{STATISTICS}

Where applicable, Student's $t$-test was used to assess the significance of differences between mean values in results. $P$ values $<0.05$ were considered significant.

\section{Results}

\section{SDS-PAGE ANALYSIS OF MUSCLE LARVAE ANTIGENS REMOVED BY CTAB}

When the levels of ${ }^{125}$ I-labelled surface antigens in the CTAB and homogenate preparations were each standardized for radioactivity $(7500 \mathrm{ct} / \mathrm{min})$ autoradiography revealed that both preparations exhibited a similar antigen profile (Figure 1). Both the CTAB preparation (Lane 2) and homogenate (Lane 1) contained surface antigens of molecular weights $100,90,69,55,46$ and 35 . Immunoprecipitation with antibody clearly 


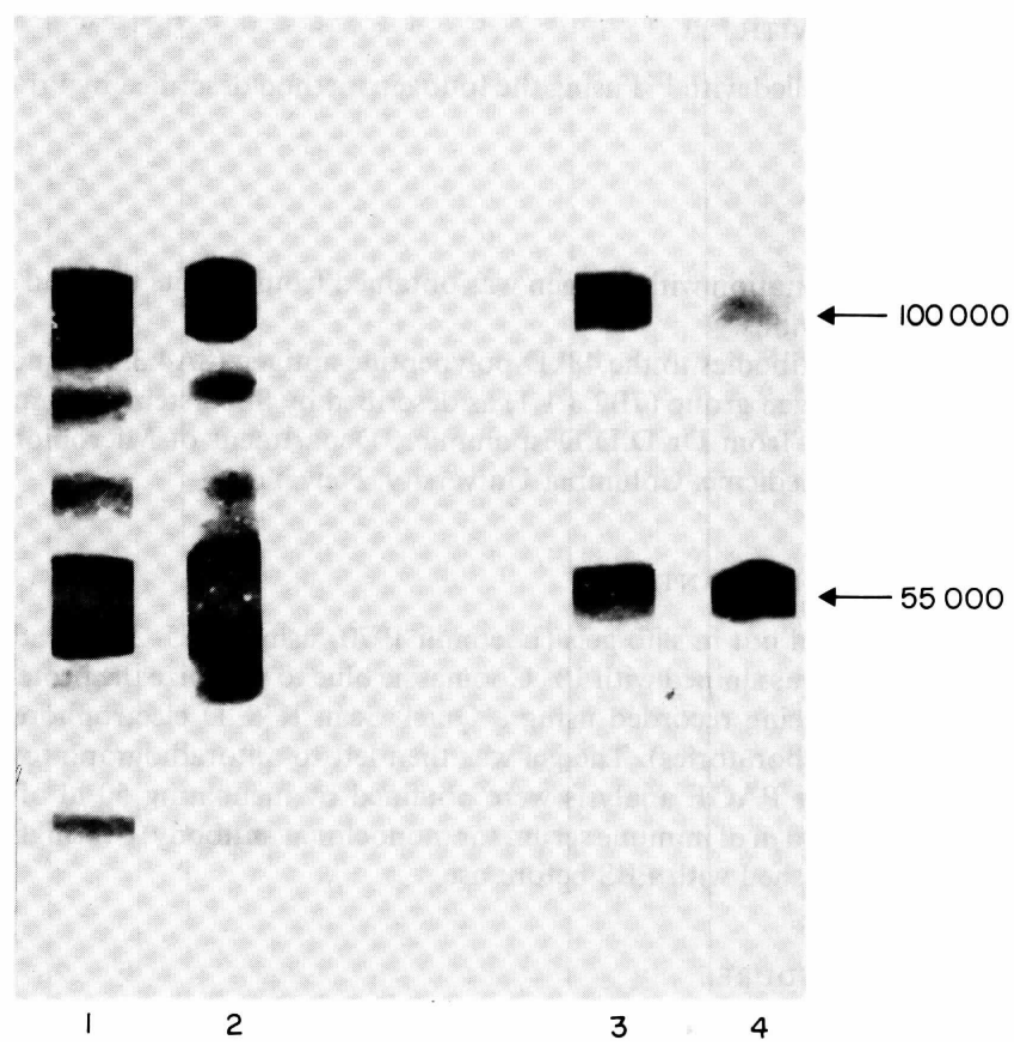

Figure 1. Comparison of $T$. spiralis muscle larvae surface antigens between homogenate and CTAB antigen preparations. Lane 1, worm homogenate; lane 2, CTAB preparation. Immunoprecipitates with hyperimmune rabbit serum (worm homogenate, lane 3; CTAB preparation lane 4).

demonstrates that all the major antigens on the surface of homogenized muscle larvae (Lane 3) were also present in the CTAB antigen preparations (Lane 4). In accordance with Pritchard et al. (1985) Coomassie blue staining demonstrated the presence of many protein bands in the homogenate, with few visible in the CTAB antigen preparations and was confirmed by comparison of densitometer tracings of muscle larvae homogenate (Lane 1) and CTAB antigen preparation (Lane 2) from the Coomassie stained gel (Figure 2).

IMMUNOPRECIPITATION OF ${ }^{125}$ I-LABELLED SURFACE ANTIGENS WITH MONOCLONAL ANTIBODIES TO $48 \mathrm{KD}$ AND 50-55 KD ANTIGENS

Monoclonal antibodies to the $48 \mathrm{kD}$ and $50-55 \mathrm{kD} T$. spiralis antigens precipitated proteins in both the CTAB antigen preparation and homogenate preparation. The data presented in Table 1 would suggest that $26 \%$ of ${ }^{125} \mathrm{I}$-labelled surface antigens present in both muscle larvae preparations shared antigenic determinants with the 50-55 kD proteins, with a smaller proportion (9-12\%) sharing determinants with the $48 \mathrm{kD}$ antigen. 


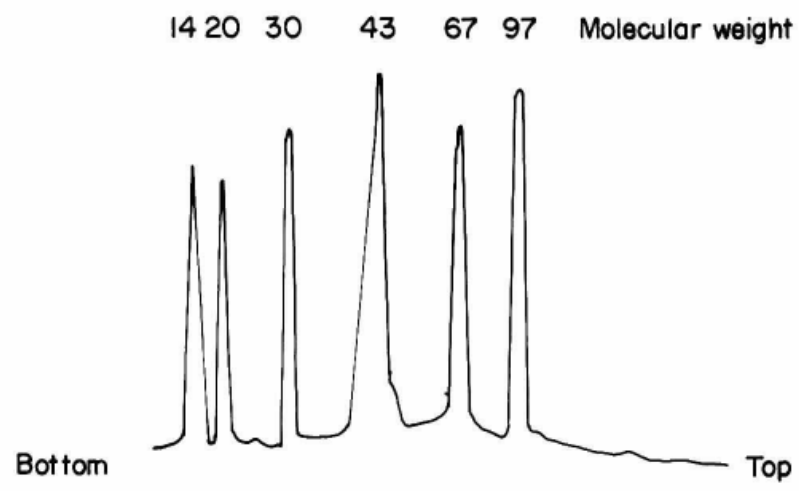

CTAB antigens
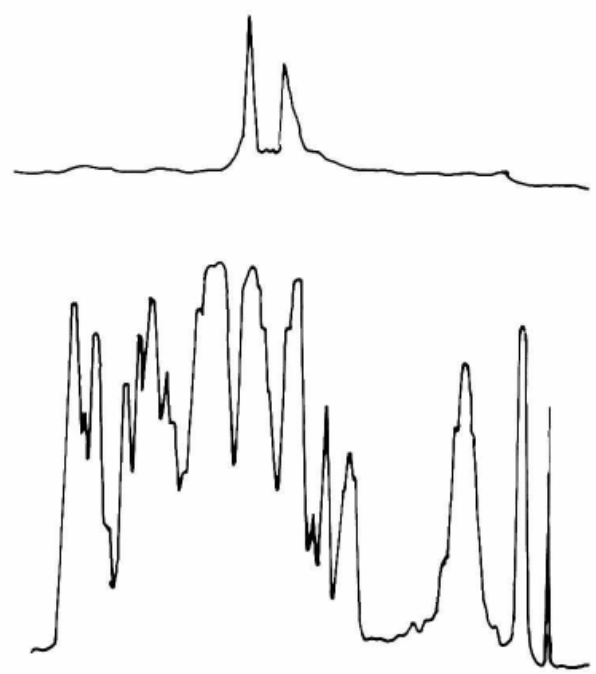

Muscle larvae

Homogenate

Figure 2. Comparison of densitometer tracings of $T$. spiralis muscle larvae antigens from Coomassie blue stained PAGE gel. Molecular weight markers, CTAB antigen preparation (lane 2) and muscle larvae homogenate (lane 1).

\section{EFFECT ON CTAB ON INFECTIVITY OF MUSCLE LARVAE}

Treatment of live muscle larvae with CTAB for $1 \mathrm{~h}$ had no effect upon the ability of the worm to establish and survive in normal mice, as assessed by adult worm burden in the small intestine recovered 8 days post infection (Figure 3 ). Mice given a prior infection (immune mice) were also able to recognize and respond to challenge with muscle larvae 
Table 1. Immunoprecipitation of ${ }^{125} \mathrm{I}-$ labelled surface antigens with monoclonal antibodies to $48 \mathrm{kD}$ and $50-55 \mathrm{kD}$ antigens

\begin{tabular}{lccc}
\hline \multirow{2}{*}{ Antigen } & Precipitating agent & $\begin{array}{c}\text { ct/min } \\
\text { in ppt }\end{array}$ & $\begin{array}{c}\text { TCA } / \text { min of } \\
\text { TCA pt }\end{array}$ \\
\hline Muscle larvae homogenate & TCA & 19545 & 100 \\
& anti-50-55 kD monoclon- & & \\
& al & 5029 & 26 \\
& anti-48 kD monoclonal & 1708 & 9 \\
CTAB antigen preparation & TCA & 7250 & 100 \\
& anti-50-55 kD monoclon- & 1894 & 26 \\
& al & 870 & 12 \\
\hline & anti-48 kD monoclonal & & \\
\hline
\end{tabular}

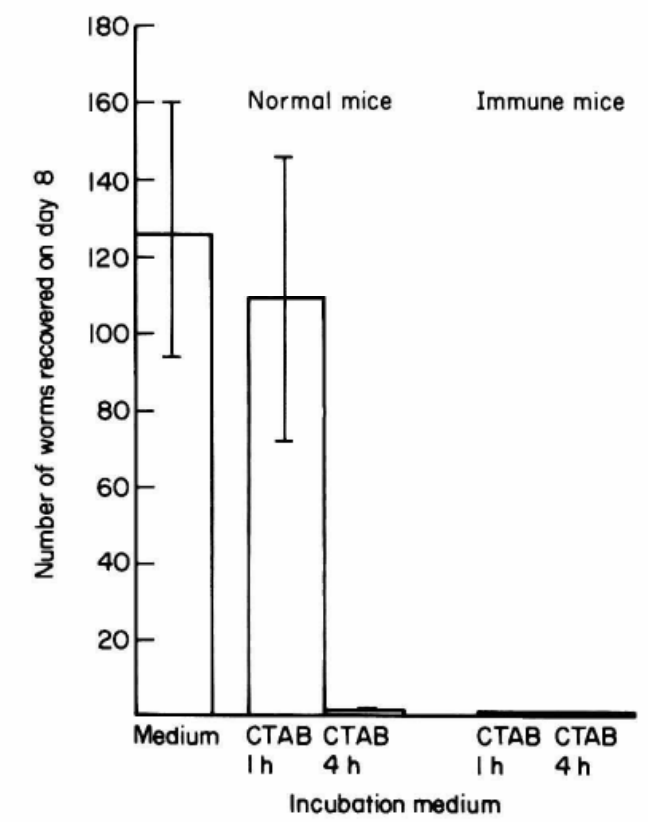

Figure 3. The effect of prior incubation of $T$. spiralis muscle larvae in $0.25 \%$ CTAB, upon their infectivity in naive and immune mice. Incubation times of $1 \mathrm{~h}$ or $4 \mathrm{~h}$. $\square$, normal mice; $\mathbf{\square}$, immune mice.

treated with CTAB for $1 \mathrm{~h}$ as shown by the accelerated expulsion of the challenge worm burden. In contrast, $4 \mathrm{~h}$ exposure of muscle larvae to CTAB drastically reduced infectivity.

Mice immunized with either homogenate or CTAB antigen preparations showed a substantial degree of protection against a challenge infection. Mean adult worm numbers 
Table 2. Immunization of mice with $\mathrm{CTAB}$ antigen or muscle larvae homogenate. Immunization with $200 \mu \mathrm{g}$ total protein in Experiment 1, $200 \mu \mathrm{g}$ total protein in Experiment 2, and $150 \mu \mathrm{g}$ total protein in Experiment 3

\begin{tabular}{|c|c|c|c|c|c|c|}
\hline \multirow{3}{*}{ Group } & \multicolumn{6}{|c|}{ Worm numbers day 8 after infection } \\
\hline & \multicolumn{2}{|c|}{ Experiment $1^{\dagger}$} & \multicolumn{2}{|c|}{ Experiment 2} & \multicolumn{2}{|c|}{ Experiment 3} \\
\hline & Mean & S.D. & Mean & S.D. & Mean & S.D. \\
\hline Control & $163 \cdot 8$ & $14 \cdot 0$ & $146 \cdot 0$ & $37 \cdot 0$ & $155 \cdot 0$ & $43 \cdot 4$ \\
\hline $\begin{array}{l}\text { CTAB antigen } \\
\text { Muscle larvae }\end{array}$ & $96 \cdot 0^{*}$ & $35 \cdot 0$ & $19 \cdot 0^{*}$ & $18 \cdot 6$ & $73 \cdot 3^{*}$ & $22 \cdot 8$ \\
\hline Homogenate & $57 \cdot 0^{*}$ & $20 \cdot 0$ & $29 \cdot 6^{*}$ & $37 \cdot 0$ & $31 \cdot 3^{*}$ & $20 \cdot 6$ \\
\hline
\end{tabular}

\footnotetext{
*Significantly different from controls

$\dagger$ Antigen administered with Freunds Incomplete adjuvant via the subcuta-
} neous route

were significantly reduced in animals immunized with CTAB antigen or muscle larvae homogenate as shown by the results from the experiments shown in Table 2. In Experiment 3 worm fecundity and worm length were measured. Furthermore an additional three mice were included in each group to assess total muscle larvae burdens. Female adult worms were stunted from animals immunized with worm homogenate (mean worm length $1.97 \mathrm{~mm}$ ) and CTAB antigen (mean worm length $2.27 \mathrm{~mm}$ ) when compared to controls (mean worm length $2.70 \mathrm{~mm}$ ). Similarly, female worms from immunized animals showed a depressed fecundity (mean number of newborn larvae shed/ $/ \mathrm{h}$; controls $5 \cdot 25$; worm homogenate 0.88 ; CTAB antigen 1.44 ). Overall protection afforded by both antigen preparations was reflected in the reduced total muscle larvae burdens of the immunized mice. (Mean muscle larvae burden per mouse; controls 24 853; worm homogenate 5 440; CTAB antigen 12320 ).

Vaccination of mice with media alone taken from a $1 \mathrm{~h}$ incubation of muscle larvae did not protect animals against a challenge infection. Worm numbers in the small intestine on day 8 after challenge (mean of $136 \cdot 8 \pm 43 \cdot 7$ ) were no different from those in controls (mean of $109 \cdot 0 \pm 33 \cdot 6)$.

\section{Discussion}

Protection by vaccination against $T$. spiralis with crude antigens prepared from muscle larvae was first achieved in the 1950s and has been described by many workers subsequently. Serologically at least 20 distinct antigens can be identified in this stage (see review by Silberstein 1983). The development of more advanced antigen purification 
techniques has allowed greater precision in identification of the molecules responsible for protective activity. Durham, Murrell \& Lee (1984) have identified a $45 \mathrm{kD}$ glycoprotein which has allergenic properties and is protective in rats. Silberstein \& Despommier (1984) have purified two polypeptides of molecular weights $48 \mathrm{kD}$ and $50-55 \mathrm{kD}$, which are protective in mice in very small quantities. Using immunoperoxidase staining, the latter two workers have shown that both polypeptides are associated primarily with the cells of the stichosome, although both polypeptides are present on the surface of the worm (Silberstein \& Despommier 1984). Using an alternative approach other workers have used iodine labelling and immunoprecipitation to probe the surface to the muscle larvae (see Parkhouse \& Ortega-Pierres 1984). These workers have shown that relatively few proteins are expressed on the surface of the worm and such antigens (molecular weights of $105 \mathrm{kD}, 89 \mathrm{kD}, 55 \mathrm{kD}$ and $47 \mathrm{kD}$ ) are presented in a stage specific manner. In the present study, similar labelling techniques showed that both the muscle larvae surface and the CTAB antigen preparation contained all the antigens described by Parkhouse and colleagues (Parkhouse et al. 1981). In addition two antigens of molecular weights $69 \mathrm{kD}$ and $34 \mathrm{kD}$ were consistently observed in both preparations. Using monoclonals to the 48 $\mathrm{kD}$ and 50-55 kD antigens (Silberstein \& Despommier 1984) iodine labelling and immunoprecipitation demonstrated that these antigens were expressed on the surface of the muscle larvae (Table 1), confirming the immunoperoxidase data obtained by Silberstein \& Despommier (1984).

The data presented here clearly demonstrates that CTAB selectively removed large quantities of all the surface antigens of $T$. spiralis muscle larvae in a relatively pure form. Removal of surface antigens with CTAB over a period of $1 \mathrm{~h}$ did not damage the worms in any critical way as infection with CTAB treated muscle larvae followed the normal course. Furthermore, such worms were recognized by previously sensitized hosts, emphasizing that the treated worms still contained protective antigens capable of stimulating immunity. Furthermore, we have shown in the present study that the CTAB antigen preparation was clearly capable of protecting mice against a challenge infection, as assessed by reduction in intestinal worm burden, worm fecundity, worm length and muscle larvae burden.

Lee, Wright \& Shivers (1984) have examined the surface layers of the cuticle of the infective muscle larvae using freeze/fracture electron microscopy. They demonstrated that the double layered structure which covers the cuticle did not fracture in a manner of a normal cell membrane. Although the outermost surface of this structure is smooth in appearance it has a substantial particular component. Furthermore, these authors suggest that this layer should not be considered comparable to the glycocalyx observed in other nematodes. The origin of this layer and its function is unknown. As previously mentioned, relatively few antigens are present on the surface of the muscle larvae, but include stichocyte derived proteins (Silberstein \& Despommier 1984; Table 1). The 48 kD and 50-55 kD antigens have been observed in the lining of the muscle larvae gut (Silberstein \& Despommier 1984), possibly as a consequence of stichocyte secretion. Stichocyte secretions are thought to play a role in extracorporeal digestion (Despommier 1983, Lee \& Wright 1978) and such secretions containing antigens could be incorporated into the surface bilayer (Silberstein 1984). Nevertheless, it is equally possible that the surface antigens are cuticle derived and are deposited when the cuticle is layed down by the hypodermis. It has recently been suggested that the $48 \mathrm{kD}$ antigen on the surface of infective muscle larvae may play a role in assisting the moulting process of the worm from 
the $\mathrm{L}_{1}$ to $\mathrm{L}_{2}$ stage (Capo, Despommier \& Silberstein 1985). The $48 \mathrm{kD}$ antigen strongly binds calcium ions (Silberstein 1984) and such a binding mechanism may restrain the muscle larvae cuticle within the worms intra-multicellular niche and thus aid ecdysis.

The stage specificity of surface antigens of the muscle larvae implies that such antigens cannot act as target molecules for the immune response which expels the adult worm from the intestine during a primary infection. Silberstein \& Despommier (1985) have suggested that, at least with respect to the $48 \mathrm{kD}$ and $50-55 \mathrm{kD}$ antigens, specific immunity does operate, but only in challenge infections in previously sensitized hosts. Alternatively, there is abundant evidence to suggest that in mice, expulsion of the adult worms is the result of non-specific intestinal inflammation generated by $T$ cells specifically activated by antigens from the early pre-adult stages of infection (see Wakelin \& Denham 1984). It is conceivable that muscle larvae antigens play a major role in this type of response. Indeed, it is known that $\mathrm{T}$ cells do respond specifically to muscle larvae antigens in vitro (Krco, David \& Wassom 1982). T cells activated by muscle larvae antigens release a variety of lymphokines, can adoptively transfer intestinal mastocytosis, peripheral blood eosinophilia and accelerate expulsion of the worm from the gut (Riedlinger, Grencis \& Wakelin 1986).

Whatever the mechanism, the data presented here clearly demonstrates that the nematode surface can play a role in the generation of protective immunity. Further work utilizing purified preparations of surface antigens will undoubtedly lead to a greater understanding of the immune processes which control parasitic nematode infections.

\section{Acknowledgements}

This work was supported by MRC project grant numbers G8218274/T and G8328675/T.

\section{References}

Bachmayer H., Liehl E. \& Schmidt G. (1976) Preparation and properties of a novel influenza subunit vaccine. Postgraduate Medical Journal 52, 360

Bell R.G. \& MCGREGOR D.D. (1979a) Trichinella spiralis: expression of rapid expulsion in rats exposed to an abbreviated enteral infection. Experimental Parasitology 48, 42

Bell R.G. \& MCGREGOR D.D. (1979b) Trichinella spiralis: role of different life cycle phases in induction, maintenance and expression of rapid expulsion in rats. Experimental Parasitology 48, 51

Bell R.G., McGregor D.D. \& Despommier D.D. (1979) Trichinella spiralis: mediation of the intestinal component of protective immunity in the rat by multiple, phase-specific antiparasite responses. Experimental Parasitology 47, 140

ButTerworth A.E. (1985) Cell mediated damage to helminths. Advances in Parasitology 23, 144

CAPO V., DesPommier D.D. \& Silberstein D.S. (1985) The anatomic site of moulting for the infective $\mathrm{L}_{1}$ larva of Trichinella spiralis. Journal of Parasitology 70, 992

Despommier D.D. (1983) In Trichinella and Trichinosis, ed W.C.Campbell, p. 75 Plenum Press, New York

DesPOMMIER D.D. \& MulleR M. (1970) Functional antigens of Trichinella spiralis. Journal of Parasitology 56, 76 
Durham C.P., MurReLl K.D. \& LeE C.M. (1984) Trichinella spiralis: Immunization of rats with an antigen fraction enriched for allergenicity. Experimental Parasitology 57, 297

KRCO C.J., DAVID C.S. \& WASSOM D.L. (1982) Characterization of an in vitro proliferation response to solubilized Trichinella spiralis antigens: role of Ia antigens and Ly-1 + T cells. Cellular Immunology 68, 359

LAEMmLi U.K. (1970) Cleavage of structural proteins during the assembly of the head of bacteriophage T4. Nature 227, 680

LeE T.D.G., Grencis R.K. \& WAKelin D. (1982) Specific cross-immunity between Trichinella spiralis and Trichuris muris: immunization with heterologous infections and antigens and transfer of immunity with heterologous immune mesenteric lymph node cells. Parasitology 84, 381

Lee D.L., Wright K.A. \& Shivers R.R. (1984) A freeze fracture study of the surface of the infective-stage larva of the nematode Trichinella. Tissue and Cell 16, 819

LEE T.D.G. \& WRIGHT K.A. (1978) The morphology of the attachment and probable feeding site of the nematode Trichuris muris. Canadian Journal of Zoology 56, 1889

Maizels R.M., PhILIPP M. \& OGILVIE B.M. (1982) Molecules on the surface of parasitic nematodes as probes of the immune response to infection. Immunological Reviews 61, 109

Parkhouse R.M.E. \& OrTega-Pierres G. (1984) Stage-specific antigens of Trichinella spiralis. Parasitology 88, 623

Parkhouse R.M.E., Philipp M. \& OGILVIE B.M. (1981) Characterization of surface antigens of Trichinella spiralis infective larvae. Parasite Immunology 3, 339

PhilipP, M., PARKhouse R.M.E. \& OGILVIE, B.M. (1980) Changing proteins on the surface of a parasitic nematode. Nature 287, 538

Philipp M. \& Rumjaneck F.D. (1984) Antigenic and dynamic properties of helminth surface structures. Molecular and Biochemical Parasitology 10, 245

Pritchard D.I., Crawford C.R., Duce I.R. \& BehnKe J.M. (1985) Antigen stripping from the nematode epicuticle using the cationic detergent cetyltrimethyl-ammonium bromide (CTAB). Parasite Immunology 7, 575

Pritchard D.I., Maizels R.M., BehnKe J.M. \& APPleby P. (1984) Stage-specific antigens of Nematospiroides dubius. Immunology 53, 325

RIEDLINGER J., GRENCIS R.K. \& WAKELIN D. (1986) Antigen specific T cell lines transfer protective immunity against Trichinella spiralis in vivo. Immunology 58, 57

SilbersteIn D.S. (1983) In Trichinella and Trichinosis, ed. W.C.Campbell, p.309. Plenum Press, New York

SilbersteIN D.S. (1984) Studies on antigens of Trichinella spiralis. Ph.D. Thesis, Columbia University, New York.

Silberstein D.S. \& DeSPOMmieR D.D. (1984) Antigens from Trichinella spiralis that induce a protective response in the mouse. Journal of Immunology 132, 898

Silberstein D.S. \& DESPOMMIER D.D. (1985) Effects on Trichinella spiralis of host responses to purified antigens. Science 227, 948

WaKelin D. \& Denham D.A. (1983) In Trichinella and Trichinosis, ed. W.C.Campbell, p.265. Plenum Press, New York

WAKELIN D. \& WILSON M.M. (1977) Transfer of immunity to Trichinella spiralis in the mouse with mesenteric lymph node cells in donors and expression of immunity in recipients. Parasitology 74, 215 